\title{
TREATMENT WITH MEBENDAZOLE IS NOT ASSOCIATED WITH DISTAL MIGRATION OF ADULT Angiostrongylus costaricensis IN THE MURINE EXPERIMENTAL INFECTION
}

\author{
Márcia Bohrer MENTZ(1), Carlos GRAEFF-TEIXEIRA(2) \& Cinara Tentardini GARRIDO(2)
}

\begin{abstract}
SUMMARY
Abdominal angiostrongyliasis is a zoonotic infection produced by a metastrongylid intra-arterial nematode, Angiostrongylus costaricensis. Human accidental infection may result in abdominal lesions and treatment with anti-helminthics is contra-indicated because of potential higher morbidity with excitement or death of worms inside vessels. To evaluate the effect of mebendazole on localization of the worms, male Swiss mice, 5 week-old, were infected with 10 third stage larvae per animal. Twelve infected mice were treated with oral mebendazol, at $5 \mathrm{mg} / \mathrm{kg} / \mathrm{day}$, for 5 consecutive days, begining 22 days after inoculation. As control groups, 12 infected but non-treated mice and other 12 non-infected and non-treated mice were studied. The findings at necropsy were, respectively for the treated (T) and control (C) groups: $92 \%$ and $80 \%$ of the worms were inside the cecal mesenteric arterial branch; $8 \%$ and $10 \%$ were located inside the aorta. Only in the group C some worms (10\%) were found inside the portal vein or splenic artery. These data indicate that treatment with mebendazole does not lead to distal or ectopic migration of A. costaricensis worms.
\end{abstract}

KEYWORDS: Angiostrongylus costaricencis; Adult stage; Migration; Mebendazole.

\section{INTRODUCTION}

Angiostrongylus costaricensis (Nematoda: Angiostrongylidae), MORERA \& CESPEDES 1971, is a nematode that lives inside the ileocolic branches of mesenteric artery of wild rodents, like the cotton rat, Sigmodon hispidus. The parasite, its cycle and the disease were first described in Costa Rica (CESPEDES et al., 1967; MORERA, 1973). Man is an accidental host, that may become infected by ingestion of food or water contaminated with third stage larvae, which may be present in the mucous secretion of veronicellid slugs, the most important intermediate host (MORERA, 1985).

The geographic range of the parasitosis includes most of the countries in the Americas, from the south of the United States to the north of Argentina (DEMO \& PESSAT, 1986; MORERA, 1988). In Brazil, the occurrence of abdominal angiostrongyliasis has been reported since 1975 (ZILIOTTO et al., 1975). The worm causes in man an infection called abdominal angiostrongyliasis, a parasitic disease characterized by a granulomatous inflammatory reaction with heavy eosinophilic infiltration of intestinal wall, especially in the ileo-cecal region (MORERA, 1967; GRAEFF-TEIXEIRA et al., 1991). Until now there is no effective medical treatment and there is even a relative contra-indication for the use of anti-helminthics, based on data reported by MORERA \& BONTEMPO (1985) suggesting that parasites were excited by the drugs instead of killed, causing erratic migration and worsening of the lesions. After these, some drug trials have demonstrated a predominant larvicidal effect, but none of those experiments was concerned with the possibility of migration of the adult worm after treatment, as it is the case in the present study, with mebendazole.

\section{MATERIALS AND METHODS}

The infective third-stage Angiostrongylus costaricensis larvae (L3), Santa Rosa strain, were inoculated through a metal canula, into 6 weekold male Swiss mice (Mus domesticus domesticus). The larvae were obtained from experimentally infected Phyllocaulis soleiformis slugs. The molluscs were digested in a $0.03 \%$ pepsin (Sigma P-7125) solution in $0.7 \% \mathrm{HCl}$ for 2 hours at $37^{\circ} \mathrm{C}$. Two groups ( $\mathrm{T}$ and $\mathrm{C}$ ) of 12 mice each, were inoculated with $10 \mathrm{~L} 3$ per animal. The first group (T), was treated with five successive doses of mebendazole (methyl 5-benzoyl-2benzimidazole-carbamate) at $5 \mathrm{mg} / \mathrm{kg} / \mathrm{day}$, starting 22 days post-infection (dpi). Mebendazole (BYC, Dinamarc) was suspended in $100 \mu \mathrm{L}$ of distilled water and given orally with a metal catheter. To both control groups, C (infected and non-treated) and $\mathrm{N}$ (non-infected and non-treated) only $100 \mu \mathrm{L}$ of distilled water was administered per os.

The animals were kept on standard laboratory conditions with food and tap water ad libitum. In order to confirm the infection, after $21 \mathrm{dpi}$ we started daily individual observation of the number of first larvae stage (L1) in feces, for seven days, using the Baermann-Moraes modified method. All surviving mice were sacrificed by $\mathrm{CO}_{2}$ inhalation at $27 \mathrm{dpi}$ and examined for the presence, number and location of adult worms. 


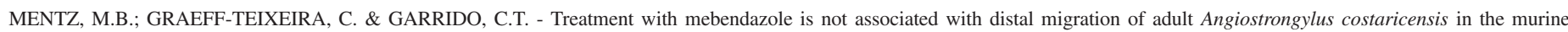
experimental infection. Rev. Inst. Med. trop. S. Paulo, 46(2):73-75, 2004

\section{RESULTS AND DISCUSSION}

The results are shown in the Table 1. Both in treated and non-treated groups most of the worms were found in their usual location, the main branches of mesenteric artery.

Efficacy of a chemotherapeutic treatment is influenced by various factors including route, dosage and regimen of the treatment. In addition, in the treatment of the diseases by tissue dwelling parasites, allergenic components of killed worms may cause adverse effects on the host (HAWKING, 1979; JOUBERT et al., 1985; HAYASHI, 1987). Therefore, effective treatment should only be established after these factors are taken into account through basic studies using experimental models.

In several experimental studies with Angiostrongylus spp, a number of parameters have been observed, like body weight, host death, relative spleen weight, pathologic changes on the serosal surface of cecum and ileum, hematologic examination, larvae elimination in feces and eggs in intestinal wall, as well as the number of recovered worms, their body length and morphologic changes (TERADA et al., 1993). Study on the localization of worms as an effect of the drug has never been performed with abdominal angiostrongyliasis.

Recent studies about mode of action of mebendazole (methyl 5benzoyl-2-benzimidazole-carbamate) suggested interruption of microtubular function as its primary mechanism of action. It secondarily inhibits glucose uptake, fumarate redutase activity, egg hatching and larval development (REW \& FETTERER, 1986). Killing effect is thought to result not only from drug action but also from the host's immune response as suggested initially by TERADA et al. (1992).

TUNGTRONGCHITR et al. (1993a) suggested that different mechanisms resulting in damage to the worms and to the host would be related to different regimens of mebendazole. When host mice were treated successively with higher doses, worms would be killed abruptly due to anthelmintic action of mebendazole, causing rather severe side effects. When mice were treated intermittently with lower doses, the worms were weakened by the anthelmintic and died more gradually through a combination of drug action and host defense, resulting in fewer side effects. A daily dose of $5 \mathrm{mg} / \mathrm{Kg}$ was selected because its efficacy and safety to treat murine angiostrongyliasis in the adult stage was demonstrated by other authors (TERADA et al., 1993; TUNGTRONGCHITR et al., 1993a).

Treatment did not reduce the number of recovered worms: 36 in the mebendazole group and 30 in control group. This seems to confirm the idea that mebendazole is predominantly a larvicidal drug, with little killing effect at adult stages, as shown by TERADA et al. (1992): the worm recovery decreased only with earlier administration, such as 10 25 days p.i.

TUNGTRONGCHITR et al. (1993b) showed that the treatment with mebendazole, even with some reduction in the number of worms, could not completely prevent host death, probably because of allergenic reactions to substances released by dead worms. In the present work, mortality was $83 \%$ in the non-treated infected control group (C group) and $67 \%$ in mebendazole treated group ( $\mathrm{T}$ group). This difference in mortality can not be attributed to a killing effect on adult worms, since their number was not reduced, but may be linked to the reduction both in the number of animals with L1 elimination (C group: 62.5\%; T group: $100 \%$ ). It could be an effect of mebendazole on egg formation and/or oviposition, as previously suggested by TERADA et al. (1993). These authors demonstrated that mebendazole can completely abolish larval output, a result only partially now reproduced, with the same successive daily dosis.

In both groups, most of the worms were located in the main branches of mesenteric artery: $24(80 \%)$ and $33(92 \%)$, respectively in control and treated groups (Table 1), in accordance with the data from TERADA et al. (1993). Only $8 \%$ of the worms in treated animals were found in the thoracic aorta, that should not be considered an ectopic location since one main route (lymphatic-arterial) for development of $A$. costaricensis includes the aorta (MOTA \& LENZI, 1995). Even if one considers it as ectopic location, it is not attributable to mebendazole, since $10 \%$ of worms in the control group were also in that location.

In conclusion, the data now reported does not support the hypothesis that mebendazole induces ectopic migration of the A. costaricensis adult worms in the murine model.

Table 1

Evaluation of mebendazole (five oral successive doses of $5 \mathrm{mg} / \mathrm{kg} / \mathrm{day}$ ) on morbidity, mortality, larvae elimination and localization of adult worms in the murine experimental infection with Angiostrongylus costaricensis

\begin{tabular}{lccc}
\hline Groups/ Parameters & Non-treated & Treated Mebendazole & Non-infected \\
\hline Infected mice & $10 / 10$ & $08 / 08$ & $08 / 10$ \\
Surviving mice & $10 / 12$ & $67 \%$ & $36 / 12$ \\
Mortality & $83 \%$ & 36 & 0 \\
Number of worms recovered & 30 & $33(92 \%)$ & $03(08 \%)$ \\
Localization of worms: & $24(80 \%)$ & $00(0 \%)$ & $05 / 08(62.5 \%)$ \\
Mesenteric artery & $03(10 \%)$ & $03(10 \%)$ & $0 \%$ \\
Thoracic aorta & $10 / 10(100 \%)$ & & \\
Splenic and portal artery & & \\
Animals with L1 in feces &
\end{tabular}




\section{RESUMO}

\section{O tratamento com mebendazol não está associado a migração distal de adultos de Angiostrongylus costaricensis na infecção experimental murina}

Angiostrongilíase abdominal é uma zoonose causada por um metastrongilídeo intra-arterial, o Angiostrongylus costaricensis. Infecção acidental humana pode resultar em doença abdominal e o tratamento com anti-helmínticos é contra-indicado pela possibilidade de agravamento das lesões com a excitação ou morte dos vermes intravasculares. Para avaliar o efeito do mebendazole sobre a localização dos vermes, camundongos Swiss machos, com 5 semanas de idade foram infectados individualmente com 10 larvas de terceiro estágio. Doze deles foram tratados 22 dias após a infecção, com mebendazole, na dose de 5 $\mathrm{mg} / \mathrm{kg} / \mathrm{dia}$, por 5 dias consecutivos. Igual número de camundongos infectados, não tratados e um terceiro grupo de animais não infectados e não tratados, serviram como grupos controles. À necrópsia observaramse os seguintes resultados: a proporção de vermes adultos encontrados na artéria mesentérica do ceco e cólon foi de $80 \%$ no grupo C e $92 \%$ no grupo T. A proporção de vermes adultos encontrados na aorta torácica foi de $10 \%$ no grupo $\mathrm{C}$ e de $8 \%$ no grupo T. No grupo C, $10 \%$ dos vermes também foram encontrados na veia porta e na artéria esplênica. Estes resultados indicam que o mebendazole não induz migração ectópica ou distal do Angiostrongylus costaricensis.

\section{REFERENCES}

1. CÉSPEDES, R.; SALAS, J.; MEKBEL, S. et al. - Granulomas entéricos y linfáticos con intensa eosinofilia tisular producidos por un strongilídeo (strongylata). Acta méd. costarric., 10: 235-255, 1967.

2. DEMO, O.J. \& PESSAT, O.A.N. - Angiostrongilosis abdominal. Primer caso humano encontrado en Argentina. Prensa méd. argent., 73: 732-738, 1986.

3. GRAEFF-TEIXEIRA, C.; CAMILLO-COURA, L. \& LENZI, H.I. - Clinical and epidemiological aspects of abdominal angiostrongyliasis in Southern Brazil. Rev. Inst. Med. trop. S. Paulo, 33: 373-378, 1991.

4. HAWKING, F. - Diethylcarbamazine and new compounds for the treatment of filariasis. Advanc. Pharmacol. Chemother., 16: 129-194, 1979.

5. HAYASHI, M. - Studies on chemotherapy of parasitic helminths. (XXX). Clinical and pathological changes in mices infected with Angiostrongylus cantonensis and treatment with mebendazole and betamethasone. Jap. J. Parasit., 36: 80-87, 1987.

6. JOUBERT, J.; JOUBERT, M.J. \& LOMBAARD, C.M. - Neurocysticercosis: a comprehensive approach to medical treatment. S. Afr. med. J., 68: 11-14, 1985.
7. MORERA, P. - Granulomas entéricos y linfáticos con intensa eosinofilia tisular producidos por un estrongilídeo (Strongylata: Raillet y Henry, 1913). II. Aspecto parasitológico (Nota prévia). Acta méd. costarric., 10: 257-265, 1967.

8. MORERA, P. - Life history and redescription of Angiostrongylus costaricensis Morera \& Céspedes, 1971. Amer. J. trop. Med. Hyg., 22: 613-621, 1973.

9. MORERA, P. - Abdominal angiostrongyliasis; a problem of public health. Parasit. today, 1: $173-175,1985$

10. MORERA, P. - Angiostrongilíase abdominal. Um problema de Saúde Pública? Rev. Soc. bras. Med. trop., 21: 81-83, 1988.

11. MORERA, P. \& BONTEMPO, I. - Acción de algunos antihelminticos sobre Angiostrongylus costaricensis. Rev. méd. Hosp. nac. Niños Costa Rica, 20: 165174, 1985.

12. MORERA, P. \& CÉSPEDES, R. - Angiostrongilosis abdominal. Una nueva parasitosis humana. Acta méd. costarric., 14: 159-173, 1971.

13. MOTA, E.M. \& LENZI, H.L. - Angiostrongylus costaricensis life cycle. A new proposal. Mem. Inst. Oswaldo Cruz, 90: 707-709, 1995.

14. REW, R.S. \& FETTERER, R.H. - Mode of action of antinematodal drugs. In: CAMPBELL, W.C. \& REW, R.S.,ed. Chemotherapy of parasitic diseases. New York, Plenum Press, 1986. p. 321-337.

15. TERADA, M.; KINO, H.; AKYOL, C.V. \& SANO, M. - Effects of mebendazole on Angiostrongylus costaricensis in mice with special reference to the timing of treatment. Parasit. Res., 79: 441-443, 1993.

16. TERADA, M.; TUNGTRONGCHITR, A.; ISHII, A. \& SANO, M. - Effects of mebendazole on abdominal angiostrongyliasis in mice after worm maturation: preliminary trials. Jap. J. Parasit., 41: 481-486, 1992.

17. TUNGTRONGCHITR, A.; ISHII, A. \& TERADA, M. - Effects of mebendazole given intermittently or successively with various doses and intervals on murine Angiostrongyliasis costaricensis after worm maturation. Jap. J. Parasit., 42: 321330, 1993a.

18. TUNGTRONGCHITR, A.; ISHII, A.; TERADA, M. \& RADOMYOS, P. - Effects of sensitization on efficacy of mebendazole in mice infected with adult Angiostrongylus costaricensis. Trop. Med. Parasit., 44: 322-326, 1993b.

19. ZILIOTTO, A.; KUNZLE, J.E.; FERNANDES, L.A.R.; PRATES-CAMPOS, J.C. \& BRITTO-COSTA, R. - Angiostrongilíase: apresentação de um provável caso. Rev. Inst. Med. trop. S. Paulo, 17: 312-318, 1975.

Received: 30 October 2003

Accepted: 10 February 2004 